\title{
A Impugnação de Julgados e o Dever Constitucional de Motivar as Decisões no Microssistema dos Juizados Especiais Federais ${ }^{1}$
}

\section{Márcio Ricardo Staffen}

Doutorando em Direito Público pela Università degli Studi di Perugia - Itália. Doutorando e mestre em Ciência Jurídica pela Universidade do Vale do Itajaí - Univali (Conceito Capes 5). Especializando em Gestão Acadêmica e Universitária pela Universidade para o Desenvolvimento do Estado de Santa Catarina (Udesc - Esag). Possui Graduação em Direito pela Universidade do Vale do Itajaí - Univali. Pesquisador do Conselho Nacional de Justiça (CNJ). Professor Honorário da Faculdade de Direito e Ciências Sociais da Universidad Inca Garcilaso de la Vega (Peru). Professor nos cursos de Graduação em Direito e Especializações no Centro Universitário para o Desenvolvimento do Alto Vale do Itajaí (Unidavi) e na Universidade do Vale do Itajaí (Univali). Coordenador do Núcleo de Prática Jurídica Unidavi. Advogado (OAB/SC). Coordenador da Escola Superior de Advocacia Subsecção Rio do Sul $(\mathrm{OAB} / \mathrm{SC})$. Realizou cursos junto à Universidade Federal de Santa Catarina UFSC, Università degli Studi di Perugia UNIPG, Università Roma Trè, Università degli Studi di Camerino Ucam, Universidad de Alicante - UA e Universidade Karlova IV (Praga). Membro do Comite da Escuela de Formación de Auxiliares Jurisdiccionales de la Corte Superior de Justicia del Callao (Peru). Membro Honorário do Ilustre Colegio de Abogados de

${ }^{1}$ Artigo desenvolvido no âmbito do Projeto de Pesquisa CNJ Acadêmico: "Juizados Especiais, Turmas Recursais e Turmas de Uniformização da Justiça Federal”. Com fomento do Conselho Nacional de Justiça (CNJ) e da Coordenação de Aperfeiçoamento de Pessoal de Nivel Superior (Capes). 
Ancash (Peru). Membro efetivo da Sociedade Literária São Bento. Membro do Conselho Nacional de Pesquisa e Pós-Graduação em Direito - Conpedi. Líder do Grupo de Pesquisa Direito, Constituição e Sociedade de Risco (GPDC-Unidavi).staffen_sc@yahoo.com.br

\title{
Resumo
}

0 presente artigo científico propõe-se, de modo coeso, a apresentar críticas ao modelo de impugnação de julgados instalado em sede de Juizados Especiais Federais à luz do dever constitucional de motivação das decisões judiciais, no qual se tolera simulacros de fundamentos jurídicos a serem consagrados nas decisões. De igual sorte, discute-se a arquitetura manejada no intuito da flexibilização do imperativo de fundamentação jurídica das decisões. Nesse sentido, impõe-se a necessidade inafastável de legitimidade constitucional das ordens judiciais proferidas, independentemente do procedimento jurisdicional adotado. Em verdade, objetiva-se a defesa de um modelo constitucional garantista de processo, notadamente nos casos de consagrada hipossuficiência dos autores perante a pujança da máquina administrativa federal. Utilizou-se, para o desenvolvimento da presente pesquisa, o método indutivo, operacionalizado pelas técnicas de conceitos operacionais e da pesquisa bibliográfica.

Palavras-chave: Juizados Especiais Federais. Motivação. Impugnação de julgados.

\section{The Impugnation of Judged and Constitutional Duty to Motivate Decisions in the Microsystem of Federal Special Courts}

\begin{abstract}
This paper proposes, cohesive way to presente critical challenges to the trial model installed in place of Special Federal Courts in the light of the constitutional duty of motivation of judgments, in which tolerates simulacra of legal grounds to be enshrined in decisions. Alsolucky, discusses the handled in order of easing the requirement of legal reasoning architecture decisions. This court impose the need for indispensable given constitutional legitimacy of judicial orders, regard lessof judicial procedure adopted. In fact, the objective is the defenseof a constitutional model garantist process, especially in cases of consecrated poverty the authors before the strength of the federal administrative machinery. Wasused for the development of this research, thein ductive method, operated by the techniques of operational concepts and literature.
\end{abstract}

Keywords: Special Federal Courts. Motivation. Impugnation of judged.

\section{Sumário}

1 Introdução. 2 Meios de impugnação de julgados nos Juizados Especiais Federais. 30 dever constitucional de motivar as decisões. 4 Considerações finais. 5 Referências. 


\section{INTRODUÇÃO}

A série de reformas no modo de prestação jurisdicional brasileiro assinala um ponto de destaque: o propósito particularmente forte de promover o ingresso de determinadas pretensões no poder Judiciário. O que se seguiria após isso passaria a ter condição acessória. Conforme já registrado em tópico específico, fica preterida, todavia, a compreensão nuclear de que a realização da Justiça se opera na facticidade das partes, independentemente do momento ou espaço institucional, judicial ou não (Bochenek, 2011, p. 248).

Este prelúdio ratifica a abordagem crítica tecida que perpassa a condição prévia ao peticionamento perante os Juizados Especiais Federais. Grosso modo, as demandas que são apresentadas no microssistema advêm muitas vezes da sonegação voluntária pelo estado de direitos fundamentais prestacionais, mediante políticas públicas satisfativas e, noutro momento, do indeferimento dos requerimentos administrativos. Passa a ser o poder Judiciário a tábua de salvação de bens jurídicos de primeira necessidade, com vantagens, porém, para o ente público. Opera-se uma sobreposição de funções administrativas e judiciais.

Assim, o primeiro rompimento neste momento que precisa ser estabelecido atinge a defesa dos Juizados Especiais Federais como um microssistema impulsionado pela constrição de hipóteses recursais. Com o devido respeito, não merece guarida a manifestação que os Juizados Especiais Federais "têm por fundamento o desestímulo à interposição de recursos a fim de ultimar, o quanto antes, a solução da lide” (Vieira, 2011, p. 8). Ou, de forma mais incisiva ainda: "A sistemática recursal nos Juizados Especiais deve ser restritiva, pois se deve estimular o acatamento da decisão de primeira instância e dificultar a possibilidade de recorrer" (Silva, 2002, p. 155). 
Certamente o sucesso material que se espera dos Juizados Especiais Federais não se limita à sonegação de prerrogativas constitucionais recursais. Isto é, a base de mensuração não pode se pautar somente por critérios quantitativos, percentual de ações julgadas em caráter definitivo no primeiro grau de jurisdição. O êxito passa pela entrega dos bens jurídicos devidos, tal qual se pensou lá no início do projeto de sistema de Juizados.

O compilado dos argumentos anteriormente consignados desenham um panorama nefasto de incoerências e inconstitucionalidades. Talvez seja uma incompreensão ampla do eixo existencial dos Juizados Especiais Federais, isenta de gravidade constitucional e distante da facticidade social. Ademais, não pode ser aceito com naturalidade um paradigma processual que dispensa a realização de audiência, quando nesta devem acontecer os principais atos e autoriza ao magistrado fixar o limite da instrução que deseja produzir, que nega recursos incidentais quando interessantes ao autor (ou seja, só admite da entidade-ré), que aceita uma sentença sintética e, finalmente, bloqueia ao máximo a interposição de recurso, isto sem comentar a possibilidade de recurso que se fundamente pelos mesmos argumentos da sentença. Que critério de Justiça é este que flameja no centro dos Juizados Especiais Federais?

\section{MEIOS DE IMPUGNAÇÃO DE JULGADOS NOS JUIZADOS ESPECIAIS FEDERAIS}

Antes, porém, de maiores contextualizações faz-se necessária uma descrição dogmática dos recursos previstos na Lei 10.259/2001. De acordo com seu artigo $5^{\circ}$, somente será admitido recurso de sentença definitiva, ainda que, feito o estudo sobre as medidas liminares, a regra impõe a irrecorribilidade das decisões que não sejam definitivas. Pela ausência de nomen juris, ficou tal espécie recursal conhecida como Recurso Inominado ou Recurso de Sentença, não podendo ser confundido com Recurso de 
Apelação. ${ }^{2}$ Caso, porém, aconteça tal impropriedade técnica, deve prevalecer a aplicação dos critérios próprios dos Juizados, em desfavor dos valores do Código de Processo Civil. ${ }^{3}$

Por sua vez a hipótese básica de cabimento do Recurso Inominado levanta outra dissonância, no que se refere aos efeitos da sentença em relação à resolução da lide, com ou sem julgamento do mérito. A literalidade do artigo $5^{\circ}$ da Lei 10.259/2001 autoriza a hipótese de cabimento apenas de sentenças definitivas. Logo, não contemplaria os processos extintos sem resolução de mérito, por meio de sentenças terminativas. Depara-se, assim, com a repristinação de critérios hermenêuticos há muito superados, isto é, continuar com a busca e aplicação da mens legislatoris. Nestes casos, caberia ao sucumbente ajuizar nova ação judicial, conforme defendem Marisa Ferreira dos Santos e Ricardo Cunha Chimenti (2010, p. 175).

Com o devido respeito, contudo, tal orientação não se apresenta como a mais coerente e juridicamente acertada. Prosseguir nesta senda importa admitir decisões judiciais, não interlocutórias, insuscetíveis

2 "O 'recurso inominado' [...] ostenta algumas diferenças significativas em relação à apelação. Em primeiro lugar, o prazo para interpor e responder o 'recurso inominado' é de dez dias (art. 42), enquanto que a apelação é de quinze dias (art. 508 do CPC). Em segundo lugar, o preparo do 'recurso inominado' deve ser feito em até 48 horas da interposição (art. 42, $\S 1^{\circ}$ ), enquanto que o preparo da apelação deve ser demonstrado no momento da interposição (art. 511). Em terceiro lugar, o 'recurso inominado' tem, em regra, apenas o efeito devolutivo (art. 43), ao contrário da apelação (art. 520). Por fim, o 'recurso inominado’ é dirigido para a Turma Recursal (art. $41, \S 1^{\circ}$ ), enquanto que a apelação é dirigida ao tribunal correspondente (art. 515)” (Rocha, 2009, p. 143).

${ }^{3}$ Nesta tônica, observa-se os prejuízos decorrentes do formalismo e, consequentemente, que acaba por habilitar instrumentos típicos do Código de Processo Civil, trazendo uma segunda adversidade séria: "Processo Civil - Agravo de Instrumento - Recurso Inominado Interposto de Sentença - Erro Grosseiro - Inaplicabilidade do Princípio da Fungibilidade Recursal. 1. Agravo de Instrumento em face de decisão que não conheceu o Recurso Inominado interposto contra sentença de mérito. 2. A interposição de recurso errôneo no lugar de Apelação, com o fito de obter reforma da sentença de mérito, não pode beneficiar-se do princípio da fungibilidade recursal, visto tratar-se de erro grosseiro, tantas vezes censurado pelo Superior Tribunal de Justiça” (Brasil, Tribunal Regional Federal da 2a Região. Agravo de Instrumento n. 200702010116761 , Rel. Des. Fed. Raldênio Bonifácio Costa. DJe 18/09/2008). 
de reexame. Não caberia, sob tal lógica, nenhum recurso pelos meios ordinários (habilitaria, entretanto, a interposição de Mandado de Segurança ou Recurso Extraordinário), violando o disposto no artigo $5^{\circ}, \mathrm{LV}$, da CRFB/1988. Há também uma preterição evidente aos princípios norteadores dos Juizados Especiais, notadamente simplicidade e economia processual. Aos eficientistas de plantão tal postura acaba por insuflar custos elevados com novas demandas, que poderiam ter sido evitadas.

Ressalte-se, neste ínterim, a ratificação de novas razões para a filiação irrestrita ao modelo constitucional garantista de processo, nas fases recursais do microssistema dos Juizados Especiais Federais. É necessária a inversão do movimento de restrição recursal para a inserção dos direitos e garantias fundamentais perante os Juizados Especiais Federais. Não se trata apenas de defender o cabimento de recurso por si só, mas, sobretudo, de estabelecer condições de vigência e validade da Constituição e propiciar meios efetivos de saneamento de irregularidades na instrução e julgamento da lide. Enfim, não é um deleite teórico, é sim a defesa de direitos constitucionalmente positivados.

Caso contrário, nas lições de Flavia da Silva Xavier e José Antonio Savaris (2009, p. 100), de que instrumento recursal utilizaria a parte que não tem admitido sua pretensão pelo juízo? Como impugnar a decisão de indeferimento da inicial por não ter sido a inicial emendada, mesmo com a necessidade de obediência à oralidade, simplicidade, informalidade e economia processual? Como impugnar o acolhimento de litispendência ou coisa julgada, dado que não se autoriza a apresentação de nova ação? Por fim, a permissividade para reexame de sentenças terminativas transcende a apreciação isolada de questões processuais, mas para o conhecimento do mérito da causa. 
Em legítima concretização da teoria dos sistemas, há de se aplicar, de igual sorte, as inovações decorrentes da Lei 12.153/2009, que institui os Juizados Especiais da Fazenda Pública, a qual autoriza a interposição de recurso para Turma Recursal diante de sentenças, independentemente da sua caracterização processual.

Em nome dos princípios da simplicidade, informalidade, economia processual e celeridade fixou-se como prazo para interposição de Recurso Inominado o lapso de dez dias, contados da ciência da sentença, com o objetivo de instituir condições mínimas de igualdade entre os litigantes para excluir a aplicação dos artigos 188 e 191 do Código de Processo Civil. Afasta-se o reexame necessário para as ações em que seja parte ente público, bem como os prazos diferenciados que se convertiam em audácias contra a administração da Justiça.

Além das hipóteses de cabimento, taxatividade e da tempestividade urge traçar sucintos paralelos acerca do recolhimento de preparo recursal. Sua primeira condição de exigibilidade ou não se condiciona à concessão dos benefícios da Lei 1.060/1950, que pode acontecer em qualquer momento processual (Enunciado 38 - Fórum Nacional de Juizados Especiais - Fonajef). Uma vez interposto o Recurso Inominado, deve o recorrente, quando compelido, no prazo de 48 horas fazer a comprovação do preparo, sob pena de deserção (Enunciado 39 - Fórum Nacional de Juizados Especiais - Fonajef).

Quanto à forma e ao conteúdo, o Recurso Inominado pressupõe a interposição patrocinada por advogado, sob forma escrita e por meio da via eletrônica. Momentaneamente sai de cena a oralidade. Caso não tenha a parte condições de prover advogado, cabe ao juiz da instrução remeter os autos à Defensoria Pública da União ou, alternativamente, a designação de advogado dativo. 
A interposição do Recurso Inominado deve ser feita ao juízo prolator da sentença. Logo, encaminhar-se-á as razões recursais para a Turma Recursal, órgão colegiado (que não se confunde com Tribunal), a quem cabe o julgamento em segunda instância. ${ }^{4} \mathrm{Na}$ versão original cada Turma era composta por três juízes federais, com período de participação de dois anos, tendo como critérios de nomeação antiguidade e merecimento. Trata-se de função temporária que impede a imediata recondução, salutar para o potencial de inovação nos julgados. ${ }^{5}$ Compete aos respectivos Tribunais Regionais Federais regulamentar as particularidades de cada Turma.

Com o advento da 12.665/2012, entretanto, fixou-se estrutura permanente para as Turmas Recursais, inclusive com a criação de cargo de juiz federal para integrá-las, ficando substituída a condição de voluntariedade na sua composição. Houve a estipulação da função de juiz suplente nas Turmas Recursais, com participação temporariamente curta (180 dias) e cumulativa com a sua Vara de titularidade. Tal quadro mostra-se impraticável pela baixa adesão dos magistrados. Para tanto, o Projeto de Lei 5.826/2013, em apreciação da Câmara dos Deputados, propõe a restaura-

\footnotetext{
4 "Art. $2^{\circ}$. Compete às Turmas Recursais dos Juizados Especiais Federais processar e julgar: I - em matéria cível, o recurso de sentença, excetuada a homologatória de conciliação ou laudo arbitral, e o de decisão que defere ou indefere medidas cautelares ou antecipatórias dos efeitos da tutela; II - em matéria criminal, a apelação de sentença e a de decisão de rejeição da denúncia ou queixa; III - os embargos de declaração opostos aos seus julgados; IV - os mandados de segurança contra ato de juiz federal no exercício da competência dos Juizados Especiais Federais e contra os seus próprios atos e decisões; V - os habeas corpus contra ato de juiz federal no exercício da competência dos Juizados Especiais Federais e de juiz federal integrante da própria Turma Recursal; VI - conflito de competência entre juízes federais dos Juizados Especiais Federais vinculados à Turma Recursal; VII - as revisões criminais de julgados seus ou dos juízes federais no exercício da competência dos Juizados Especiais Federais” (Brasil, Conselho da Justiça Federal. Resolução n. 61/2009. Disponível em: <www.cjf.jus.br>. Acesso em: 11 jan. 2014a).

${ }^{5}$ Para alguns, este diagnóstico mascara um lado insidioso, pois mantém um constante palco de instabilidade nos julgados (Xavier; Savaris, 2009, p. 84).
} 
ção da possibilidade de convocação pelos Tribunais Regionais Federais de juízes suplentes, preferencialmente vinculados aos Juizados Especiais Federais, para que integrem as Turmas Recursais.

No que diz respeito às razões recursais, o Recurso Inominado admite ampla fundamentação destinada à impugnação do julgado e os elementos que produziram a decisão judicial. Busca reformar ou anular o julgado impugnado mediante devolução da matéria. Além disso, é o momento apropriado para a análise diferida das decisões interlocutórias, nos termos do artigo $4^{\circ}$, Lei 10.259/2001 e Enunciado 107, do Fonajef. O resultado das decisões é tomado pela maioria simples dos juízes.

Em passagens anteriores registrou-se como peculiaridade do sistema dos Juizados Especiais o recebimento de Recurso Inominado unicamente com o efeito devolutivo, todavia, de igual sorte de argumentos já consignados, quando a sucumbência pesar contra a administração pública e seus entes, o recurso será recebido com efeito duplo: suspensivo e devolutivo. Trata-se de adequação à necessidade de trânsito em julgado de sentenças condenatórias para que a administração pública faça a satisfação da obrigação. Deste modo, tem-se a imediata suspensão da eficácia da sentença até o final do julgamento do recurso (Vieira, 2011, p. 49). Apenas conceder-se-á efeito devolutivo nos casos de antecipação de tutela ou medida cautelar de urgência (Enunciado 61 - Fonajef).

Por seu turno, reafirma-se a confirmação da hipótese de valia do microssistema dos Juizados Especiais Federais como via judicial de cunho estamental a serviço do Estado brasileiro, que dele se utiliza para privilégios injustificados.

Diversamente do que se passa na sistemática recursal ordinária do Código de Processo Civil, o Recurso Inominado tem a apreciação de seus requisitos de admissibilidade apenas pelo juiz relator na Turma Recursal 
(Enunciado 34 - Fonajef), ${ }^{6}$ com as contrarrazões devendo ser aderidas antes do juízo de admissibilidade (Enunciado 36 - Fonajef). Não recebido o Recurso Inominado, entretanto, múltiplas são as divergências sobre o instrumento judicial de remédio. Os debates pairam sobre o cabimento de Mandado de Segurança (a partir de um viés constitucional) ou Agravo de Instrumento ${ }^{8}$ (em analogia ao Código de Processo Civil). Seguindo as linhas articuladas até o momento, acredita-se ser o caso de Mandado de Segurança, pela prioridade de aplicação da Constituição Federal e preenchimento de seus requisitos que se sobrepõem ao chamamento do Código de Processo Civil.

Além dos demais requisitos, intrínsecos e extrínsecos para o processamento do Recurso Inominado junto à Turma Recursal competente, deve o juiz relator mensurar eventuais causas de manifesta inadmissibilidade, improcedência, prejudicado ou em confronto com súmulas, enunciados ou jurisprudência dominante da Turma Nacional de Uniformização, do Superior Tribunal de Justiça ou do Supremo Tribunal Federal. Ao relator competirá negar seguimento, com fulcro no artigo 557 do Código de Processo Civil, defende Luciano Pereira Vieira (2011, p. 61).

${ }^{6}$ Diverge neste ponto a Turma Recursal Federal do Rio de Janeiro: "Enunciado 17 - Quando não houver prévia análise da admissibilidade pelo juiz a quo, a mesma será efetuada pelo relator, sem devolução ao juizado de origem.”

7 “[...] Não havendo previsão legal de recurso contra decisão interlocutória que não recebeu o recurso inominado interposto e não sendo o ato impugnado uma sentença definitiva, cabível, portanto, o mandado de segurança contra o ato judicial praticado por Juiz singular do Juizado Especial Federal” (Brasil. Turma Recursal de São Paulo. Mandado de Segurança n. 201063010076231. Rel. Juiz Federal Claudio Roberto Canata. Julgado em 4/2/2010). Disponível em: <www.trf3r.jus.br >. Acesso em: 5 jan. 2014e.

8 "Processual Civil. Mandado de segurança Contra Ato Judicial. Decisão que não conheceu de Recurso por Intempestividade. Inadequação da via eleita. Segurança Denegada. [...] Contra decisão vergastada poderia ter sido interposto agravo de instrumento, conforme entendimento consolidado por esta Turma Recursal na leitura que faz dos arts. $4^{\circ}$ e $5^{\circ}$ da Lei 10.259/2001" (Brasil. Primeira Turma Recursal do Distrito Federal. Mandado de Segurança n. 200534007545820. Rel. Juiz Federal Alexandre Machado Vasconcelos. Julgado em 9/11/2007). Disponível em: <www.trf1r.jus.br>. Acesso em: 5 jan. 2014b. 
Mesmo que tal posição acabe se sustentando nos Enunciados 102 e 103 do Fonajef, não há como se conformar com tal moldura. Os argumentos representam inegável intuito de sonegar jurisdição. Em especial, pretendem alocar requisitos recursais não previstos na esfera dos Juizados Especiais Federais. Além da ausência de previsão constitucional e legal expressa, tenta transfigurar condições exclusivas ao Processo Civil. Não se compatibiliza com os critérios norteadores do sistema. Deve, portanto, ser vergastada, em favor dos esteios centrais do modelo constitucional garantista de processo pretendido.

Não por acaso, persiste a contumaz apresentação de um paradigma recursal altamente impermeável por suas próprias razões, produzidas internamente ao alvedrio da ordem jurídica. Distancia-se em milhas da oralidade, da simplicidade, da informalidade... Talvez, sem que haja uma justificativa juridicamente coerente, apoia-se na celeridade e economia processual. Na verdade, é demasia de burocratização. Explicita burocracia própria e fiel ao Estado brasileiro, comprovando as ideias desenvolvidas na introdução deste texto.

Felizmente, por diversas forças o microssistema dos Juizados Especiais Federais oscila em polos distintos. Além do que já restou escrito, pode-se citar também a autorização pertinente para que as Turmas Recursais possam complementar os atos de instrução já realizados pelo Magistrado do Juizado, de forma a evitar a anulação de sentença (Enunciados 94, 95 e 101 - Fonajef), podendo ou não baixar em diligência (Enunciados 96 e 103 - Fonajef), custas somente para a parte totalmente sucumbente (Enunciado 57 - Fonajef), como exemplos de inovações frutíferas para os indivíduos.

Há, todavia, algo mais significativo que por sua condição sui generis será abordado em item específico: a confirmação pelos próprios fundamentos da sentença. 
Originariamente, além do Recurso Inominado, o sistema dos Juizados Especiais trouxe em seu bojo o cabimento de Embargos de Declaração como meio de impugnação dos seus julgados. Caberão embargos declaratórios quando, na sentença ou acórdão, se apresentar obscuridade, contradição, omissão ou dúvida (artigo 48, Lei 9.099/1995). A literalidade das hipóteses de cabimento trazem clara divergência ao previsto no Código de Processo Civil. Logo, razão suficiente para reforçar os marcos divisórios de cada sistema. A possibilidade de apresentação de Embargos de Declaração por dúvida no julgado, erradicada do CPC na reforma provida pela Lei 8.950/1994, manteve-se intacta no sistema dos Juizados Especiais. Não é, porém, uma peculiaridade exclusiva na interação dos referidos sistemas processuais. Outra diferença relevante surge quando da suspensão do prazo recursal com a apresentação dos embargos contra sentença (artigo 50, Lei 9.099/1995), porém, se os embargos versam contra acórdão o prazo é interrompido (Xavier; Savaris, 2009, p. 124).

Seguindo os postulados do critério da oralidade, impõe-se como meio eficaz de minimização da sua utilização a redação das decisões com objetividade, clareza e simplicidade. Não se deve converter as manifestações de mérito em um exercício de erudição, pois há de afrontar as condições dos autores, por vezes não assessorados por advogados, bem como pela escassez de servidores disponíveis para orientação em virtude das atermações.

Ainda no que respeita à oralidade e à simplicidade, admite-se a apresentação de Embargos de Declaração, no prazo de cinco dias, além da via escrita, também oralmente. Descortina-se, contudo, um aspecto comprometedor nesta opção. A verbalização oral pode não ser suficiente para expressar a exata dimensão da contradição, omissão, dúvida ou obscuridade. Ademais, justifica-se esta opção quando da prolação de sentença em audiência. 
A legitimidade para opor Embargos de Declaração não se condiciona à sucumbência, total ou parcial. A função social desta medida é satisfazer o dever consignado no artigo 93, IX, da CRFB/1988, ou seja, promover uma decisão juridicamente fundamentada com coerência, imperativo relevante de um modelo constitucional garantista de processo (embora, não devesse a ordem constitucional admitir a ocorrência de tais decisões). Existindo, portanto, contradição, omissão, dúvida ou obscuridade são cabíveis embargos declaratórios. Estes mesmos argumentos justificam o cabimento de Embargos de Declaração contra decisão interlocutória.

Como regra geral, os Embargos de Declaração não são habilitados a promover a modificação material dos julgados. Objetivam sanar ou complementar a decisão embargada, todavia, em favor da economia processual e da celeridade admite-se a procedência de embargos com efeitos infringentes excepcionalmente, somente na constância de omissão, contradição, obscuridade e dúvida de tal envergadura que provoque a necessidade de alteração do mérito da decisão. Importante frisar a compulsoriedade de se assegurar o contraditório nestes casos, haja vista a condição modificativa do ato decisório. ${ }^{9}$

\footnotetext{
9 "Para melhor visualização da questão, tome-se um exemplo recorrente nos Juizados Especiais Federais: ajuizada uma ação para buscar a condenação ao pagamento de danos morais e materiais, a parte ré apresenta resposta em que suscita a prejudicial de mérito da prescrição e, por observância do princípio da eventualidade, também deduz todas as suas defesas de mérito. O magistrado, ao julgar a causa, limita-se apenas a analisar e refutar as defesas de mérito invocadas e omite-se quanto à apreciação da prescrição. Julga, então, procedente o pedido da parte autora. Uma vez instado a se manifestar expressamente sobre a prejudicial em embargos de declaração, fica evidenciada a consumação do prazo prescricional. Em situação como essa, é incontestável que a omissão merece ser suprida com o reconhecimento da prescrição e atribuição de excepcionais efeitos infringentes aos embargos, pois a nova decisão proferida acabará extinguindo o feito com uma decisão de mérito (CPC, art. 269, IV) favorável à parte ré. Apenas suprir a omissão reconhecendo a consumação do prazo prescricional, sem alterar o conteúdo decisório, importará em nova causa de interposição de embargos, pois, dessa vez, ficará caracterizada a contradição. Destarte, em situação extrema como essa, é de se admitir excepcionais efeitos infringentes aos embargos de declaração" (Xavier; Savaris, 2009, p. 145-146).
} 
Além da função típica dos Embargos de Declaração, cabe não descuidar dos objetivos prequestionatórios que compõem os motivos de sua utilização. Conforme já fixou o Fonajef, Enunciado 54, não se exige prequestionamento da matéria para interposição de Recurso Inominado, contudo o cabimento de incidentes de uniformização de jurisprudência (artigo 14, Lei 10.259/2001) e de recurso extraordinário exige o explícito pré-questionamento pela instância ordinária.

Neste sentido, análise pormenorizada há de ser direcionada à Questão de Ordem 10, da Turma Nacional de Jurisprudência dos Juizados Especiais Federais, a qual afirma não caber incidente de uniformização quando a parte que o deduz ventila tese jurídica inovadora, não apresentada nas fases anteriores do processo e não debatida expressamente pela Turma Recursal competente.

Com a devida prudência, detecta-se uma dissonância clara deste verbete para com os critérios norteadores dos Juizados Especiais Federais em si. Observa-se condição material de incompatibilidade entre informalidade, simplicidade e economia processual com a demasia procedimental nesta fase, não raras vezes permutada com o Código de Processo Civil irracionalmente. Ao se admitir a desburocratização e a baixa formalidade na condução da lide, permitindo, inclusive, decisões com fundamentação sintética, como se exigir o claro e exauriente pré-questionamento da matéria, que não se obtém por meio de Embargos de Declaração ${ }^{10}$ Em suma, reclama

\footnotetext{
${ }^{10}$ Apenas para ilustrar as idiossincrasias amealhadas: "Processo Civil. Embargos de declaração. Prequestionamento. Embargos improvidos. 1. Mesmo para fins de prequestionamento a interposição de embargos de declaração carece de configuração das hipóteses do art. 535 do Código de Processo Civil (omissão, obscuridade ou contradição), de modo que somente se mostra cabível quando há efetiva omissão sobre a questão relevante suscitada pelas partes. 2. A exigência de fundamentação do art. 93, X, da Constituição Federal se satisfaz com a exposição das razões que suportam a conclusão judicial, sem exigir manifestação expressa e minuciosa acerca de todas as alegações da parte, haja vista que as decisões judiciais se destinam a dirimir a lide, e não a rebater todas as teses suscitadas pelos procuradores da parte. 3. Embargos de declaração improvidos" (Brasil. Turma Regional de Uniformização - $4^{\mathrm{a}}$ Região. Autos 2005.7.60.002724-9-RS. Rel. Juiz Federal Andrei Pitten Velloso, publicado em 8/1/2010).
} 
das partes atributos alheios a sua esfera de faculdades processuais, com o ônus mais denso pesando sobre o autor pelo alvedrio na constituição de advogado. Ou seja, aquele que optou pela adoção dos princípios dos Juizados Especiais poderá ser penalizado por ato alheio a sua vontade no exercício de legítimo direito constitucionalmente consagrado. Logo, ratifica-se o aspecto insidioso do paradigma de impugnação de julgados nos Juizados Especiais Federais e sua violação à Constituição Federal.

Além das vias ordinárias de impugnação de julgados no microssistema dos Juizados Especiais Federais, merecem sucintos apontamentos os meios excepcionais de estrito direito. Dentre estes, o recurso de maior envergadura é o Recurso Extraordinário, previsto no artigo 102, III, da CRFB/1988. Tal Recurso exige, para seu conhecimento, o esgotamento das vias recursais ordinárias, o prequestionamento da questão constitucional e a sua repercussão geral. Não por acaso guarda conexão com os elementos essenciais para incidentes de uniformização previstos na Lei 10.259/2001: exigência de prévio esgotamento das vias recursais, revisão de questões de Direito e saneamento de pontos jurídicos. A linha de corte, no entanto, está na apreciação da questão constitucional como núcleo do Recurso Extraordinário, enquanto os incidentes pautam-se pelo julgamento em sede de legislação infraconstitucional. Isto, porém, não significa a cisão dos conteúdos sujeito à apreciação, pois a análise de questões constitucionais é condição elementar de todos os poderes públicos.

Em virtude do verbete sumular 640 do STF cabe recurso extraordinário contra decisão proferida por juiz de primeiro grau nas causas de alçada, ou por Turma Recursal de Juizado Especial Cível e Criminal. Logo, o esgotamento opera-se com decisão exarada por Turma Recursal, dispensada a remessa para as Turmas de Uniformização.

A interposição do Recurso Extraordinário exige o peticionamento eletrônico, no prazo de 15 dias, em preliminar arguir a repercussão geral. A violação constitucional, exposição fática e jurídica, demonstração de cabimento 
e as razões de reforma da decisão devem ser ventiladas em petição distinta. Requer-se preparo. Por seu turno, em regra será processado apenas no efeito devolutivo, salvo manejo de medida cautelar. Ressalte-se que negado seguimento ao Recurso Extraordinário, pelo presidente da Turma, torna-se cabível a interposição de Agravo de Instrumento (Súmula 727 - STF).

Ainda sobre o juízo de repercussão geral, impõe advertir para a necessidade de remessa pelas Turmas de origem, de um ou mais recursos representativos da controvérsia, sobrestando os demais. Negada a repercussão geral, os recursos sobrestados serão automaticamente não admitidos Decidido o mérito, cabe às Turmas declará-los prejudicados ou manifestar juízo de retratação Uma vez mantida a decisão, poderá o Supremo Tribunal Federal cassar ou reformar, liminarmente, o acórdão desafiante ao julgamento consolidado.

Excepcionalmente admite-se em sede de Juizados Especiais Federais o manejo de irresignações recursais ao Superior Tribunal de Justiça, nos termos do artigo $14, \S 4^{\underline{0}}$, da Lei $10.259 / 2001$. Trata-se de caso isolado que visa a satisfazer pedido de uniformização oriundo de decisão proferida pela Turma Nacional de Uniformização que contraria súmula ou jurisprudência dominante do Superior Tribunal de Justiça. Com isso, além da possibilidade de afinação das interpretações por órgãos judiciais distintos, produz, por via oposta e mascarada, hipótese de sujeição não prevista em lei da Turma Nacional de Uniformização perante o Superior Tribunal de Justiça. ${ }^{11}$

\footnotetext{
11 "Conclui-se que o efeito externo do incidente de uniformização ao STJ ultrapassa o conceito de orientação persuasória, mas, em certa medida, vincula as instâncias inferiores dos Juizados Especiais Federais, reforçando o raciocínio de que este sistema recursal hierarquizado foi concebido para privilegiar a observância de precedentes firmados pelas cortes superiores, sobretudo quando decorrentes de uniformização de jurisprudência. (...) Nestes casos, a premissa de direito deverá ser aplicada pelas Turmas Recursais de origem que exercerão juizo de adequação - quando houver julgamento no mesmo processo em que foi decidido o incidente - ou retratação - quando houver nova decisão nos processos sobrestados, consoante o disposto no art. 14, $\S 9^{\circ}$, da Lei 10.259/2001” (Xavier; Savaris, 2009, p. 271-271).
} 
Sem desprezo às demais formas de impugnação, a saber: mandado de segurança, reclamação, ação rescisória, ação declaratória e recurso contra decisão que aprecia tutela de urgência, faz-se de singular relevância introito procedimental à uniformização de julgados por meio da interposição de incidentes.

Neste quesito, depara-se com distinção essencial entre as figuras recursais comuns e os incidentes de uniformização de julgados. $\mathrm{O}$ primeiro paira sobre os órgãos responsáveis por sua apreciação. Enquanto os recursos passam pelo crivo das Turmas Recursais, os recursos/incidentes de uniformização de julgados sujeitam-se a análise das Turmas Regionais de Uniformização ou, quando cabível, da Turma Nacional de Uniformização.

As Turmas Regionais de Uniformização, com fulcro no artigo 14, da Lei 10.259/2001, consagra peculiaridade própria do microssistema dos Juizados Especiais Federais. Objetiva, sobremodo, promover um padrão uniforme de arquitetura jurisprudencial, no âmbito de cada Tribunal Regional Federal, estabelecendo bases sólidas de pacificação jurisprudencial acerca da interpretação da lei federal. Especificamente, a composição de cada Turma de Uniformização é materializada por lacuna legal. Cabe a cada Tribunal Regional fixar seus critérios, todavia soa mais acertada uma composição permanente, que congregue juízes e/ou desembargadores federais integrantes das Turmas Recursais, com rotatividade temporária, ao invés de se fazer apenas o chamamento itinerante dos juízes das Turmas Recursais em colidência. ${ }^{12}$

No que tange à competência das Turmas Regionais de Uniformização, coube ao artigo $4^{\circ}$, da Resolução 61/2009, do Conselho da Justiça Federal, fixar, nos seguintes limites, o julgamento de: incidente regional de uniformização de jurisprudência; embargos de declaração opostos aos

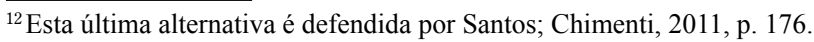


seus atos; agravo regimental da decisão do relator e do presidente. Analogicamente, admite-se competência para julgar de Mandado de Segurança contra ato de juiz federal no feitio de funções de Turma Regional.

Neste ínterim surge outro aspecto deveras controvertido, ou seja, a possibilidade de extinção das Turmas Regionais de Uniformização, com a eventual conversão em lei do Projeto de Lei 5.286/2013. Trata-se de medida ventilada pelo Conselho de Justiça Federal que afirma se deparar nesta estrutura com os maiores quadros de paralisia na prestação da tutela jurisdicional. A partir da extinção, as divergências serão transferidas para a Turma Nacional de Uniformização, promovendo nesta os mesmos entraves. Grosso modo, em provérbios vulgares vislumbra-se o dito: "Trocar seis por meia dúzia”. Continuar-se-á com os mesmos vícios, com chance real de prejuízo pela estrutura de que dispõe a Turma Nacional de Uniformização e o atual volume de demanda. Ao que consta, promover-se-á uma maciça realocação de manifestações processuais para órgão já existente sem a devida potencialização de suas capacidades para absorção dos novos pedidos de incidentes

Outro órgão revisor peculiar ao microssistema dos Juizados Especiais Federais é a Turma Nacional de Uniformização, presidida pelo ministro Coordenador-Geral da Justiça Federal e composta de dez juízes federais, com mandato de dois anos, vedada a recondução. Sua competência jurisdicional permeia a análise de pedido fundado em divergência entre decisões de turmas de diferentes regiões ou da proferida em contrariedade à súmula ou jurisprudência majoritária do Superior Tribunal de Justiça.

Aqui, urge abrir parênteses para estabelecer comparação entre a estrutura judiciária ordinária e a posta em funcionamento nos Juizados Especiais Federais. Sem levar em consideração todos os instrumentos de negação de jurisdição, mas ciente da suposta distinção entre valoração fática e valoração jurídica, uma demanda hipoteticamente ajuizada em uma Vara Federal qualquer ( $1^{\circ}$ grau), pode transitar pelo respectivo Tribunal 
de Regional Federal ( $2^{\circ}$ grau), depois pelo Superior Tribunal de Justiça ( $3^{\circ}$ grau) e, finalmente pelo Supremo Tribunal Federal ( $\left.4^{\circ} \mathrm{grau}\right)$, caso discuta-se violação de preceito constitucional. Se, no entanto, a competência para conciliar, instruir e julgar tal demanda seja encampada pelos Juizados Especiais Federais (1 $1^{\circ}$ grau), admite-se saneamento do julgado pela Turma Recursal ( $2^{\circ}$ grau), pela Turma Regional de Uniformização ( $3^{\circ}$ grau), pela Turma Nacional de Uniformização ( $4^{\underline{0}}$ grau) e, excepcionalmente pelo Superior Tribunal de Justiça ( $5^{\circ}$ grau) e pelo Supremo Tribunal Federal ( $6^{\circ}$ grau).

Evidencia-se, neste panorama, a potencialização da burocracia estatal em sede de Juizados Especiais Federais, isenta de comparação com os demais organogramas judiciários brasileiros. Duras são as críticas que se podem admitir em comparação com os critérios norteadores do sistema. O intuito de minimização de burocracia, que teve início nos idos de 1980, fora rompido pela ampliação de estruturas burocráticas, tanto no nível vertical quanto no nível horizontal. Críticas, inclusive, que atingem a validade constitucional da Turma Nacional de Uniformização (Cavalcante, 2007), pois se avança sobre competência originariamente prevista para o Superior Tribunal de Justiça (seria o caso de uma norma infraconstitucional alterar o disposto na Constituição Federal).

Considerando a predominância de efeito devolutivo nos recursos, bem como a condição de pacificação de divergências dos julgados em sede de Turmas de Uniformização, todo o organograma acaba por retroalimentar em múltiplas vezes as pautas de julgamento dos juizados e das turmas recursais. ${ }^{13}$ Promove-se uma espiral quase que infinita de recursos neste

\footnotetext{
13 "Questão de Ordem 1 - TNU - 1. Os Juizados Especiais orientam-se pela simplicidade e celeridade processual nas vertentes da lógica e da política judiciária de abreviar os procedimentos e reduzir os custos. 2. Diante de divergência entre decisões de Turmas Recursais de Regiões diferentes, o pedido de uniformização tem a natureza jurídica de recurso, cujo julgado, portanto, modificando ou reformando, substitui a decisão ensejadora do pedido. 3. A decisão constituída pela Turma de Uniformização servirá para fundamentar o juízo de retratação das ações com o processamento sobrestado ou para ser declarada a prejudicialidade dos recursos interpostos.”
} 
microssistema, ${ }^{14}$ muitos dos quais manejados por entes públicos federais que ganham tempo para a adimplência das obrigações (eis nova apresentação dos vícios estamentais). ${ }^{15}$

O escore de praticamente $50 \%$ de incidentes que voltam às Turmas Recursais para adequação do julgado à premissa de Direito uniformizada ou que podem desafiar recursos para o STJ e para o STF demonstra a necessidade e a funcionalidade da Turma Nacional de Uniformização, mas projeta um agravante numérico à taxa de congestionamento de processos de competência dos Juizados Especiais Federais. ${ }^{16}$ Demonstra-se, por outro viés, como o metavalor da segurança jurídica não se apresenta com habilidade para minimizar os volumes recursais e otimizar a razoável duração do processo.

Enquanto expediente recursal, os incidentes de uniformização de julgados para seu conhecimento clamam pelos seguintes pressupostos gerais: legitimidade, detida pelas partes e Ministério Público Federal; interesse, vinculado à sucumbência e ao interesse na estabilização das decisões; prazo de dez dias; divergência na interpretação acerca das questões de direito material atual, com evidente similitude fático-jurídica entre a decisão recorrida e o acórdão paradigma; a decisão impugnada ter sido

\footnotetext{
14 "Questão de Ordem 6 - TNU - Se a Turma Nacional decidir que o incidente de uniformização deva ser conhecido e provido no que toca a matéria de Direito e se tal conclusão importar na necessidade de exame de provas sobre matéria de fato, que foram requeridas e não produzidas, ou foram produzidas e não apreciadas pelas instâncias inferiores, a sentença ou acórdão da Turma Recursal deverão ser anuladas para que tais provas sejam produzidas ou apreciadas, ficando o juiz de $1^{\circ}$ grau e a respectiva Turma Recursal vinculados ao entendimento da Turma Nacional sobre a matéria de direito."

${ }^{15}$ Não por acaso haja evidente comemoração institucional pela capacidade da Justiça Federal em propiciar retorno monetário aos cofres públicos pela forma de arrecadação. Em 2012, as despesas totais de arrecadação foram de 7 bilhões, enquanto a receita atingiu a ordem de 9 bilhões de reais. Fonte: Conselho Nacional de Justiça. Relatório Justiça em Números. 2013. p. 185.

${ }^{16}$ Fonte: Conselho Nacional de Justiça. Relatórios Justiça em Números. 2007, 2008, 2009, 2010, 2011 e 2012.
} 
proferida por Turma Recursal; imprescindibilidade do prequestionamento e afastamento de apreciação de questões fáticas e reapreciação de provas (Xavier; Savaris, 2009).

Além destes pressupostos, faz-se necessário destacar outras particularidades recursais comuns aos incidentes de uniformização: a) efeito da interposição, ainda que em tese todos os recursos do sistema dos Juizados Especiais sejam recebidos no efeito devolutivo, há de se avaliar a conjunção com o efeito suspensivo, seja pela irreparabilidade dos danos provenientes da decisão, seja pela suspensão do cumprimento da decisão proferida no processo em que foi interposto o recurso (artigo 14 , $\S 6^{\circ}$, Lei $10.259 / 2001)$; b) produção de efeitos internos, no limite da lide em apreciação e, efeitos externos, cuja consolidação aplica-se em outros processos, estabelecendo a estandartização de julgados; c) possibilidade de interposição simultânea de incidentes de uniformização perante a Turma Regional e a Turma Nacional de Uniformização do caso de dupla caracterização das hipóteses de cabimento; d) juízo de admissibilidade duplo, pelo juizo ad quo e juizo ad quem, nos casos de negativa pelo primeiro, possibilidade de Pedido de Submissão (artigo 15, Lei 10.259/2001); e) limite de devolução do incidente no estrito campo da divergência apresentada; f) retenção de incidentes de uniformização idênticos (valendo-se da técnica da causa piloto) $;{ }^{17}$ e g) juízo de adequação e/ou juízo de retratação ao caso recorrido e aos demais similares ${ }^{18}$ ao paradigma, sob pena de Reclamação para a Turma Nacional de Uniformização.

\footnotetext{
17 "Trata-se de uma técnica conhecida em diversos países, que a denominam de 'caso-piloto', 'caso-teste' ou 'processo mestre'. Consiste o mecanismo em permitir que, entre várias demandas idênticas, seja acolhida uma só, a ser decidida pelo tribunal, aplicando-se a sentença aos demais processos que haviam ficado suspensos. Esse método é utilizado pela Alemanha, Áustria, Dinamarca, Noruega e Espanha (nesta, só para o contencioso administrativo)" (Grinover, 2008, p. 5).

18 “Enunciado 97 - Fonajef - Cabe à Turma de Uniformização reformar os acórdãos que forem contrários à sua jurisprudência pacífica, ressalvada a hipótese de supressão de instância, em que será cabível a remessa dos autos à Turma de origem para fim de adequação do julgado."
} 
Some-se às particularidades já arguidas sobre o incidente de uniformização para o Superior Tribunal de Justiça os pontos próprios de tratamento de incidentes perante a Turma Regional e a Turma Nacional de Uniformização. Além dos pressupostos e requisitos anteriormente enumerados, há de se incluir, quando da competência da Turma Regional de Uniformização, a compulsória divergência jurisprudencial entre Turmas Recursais que compõem o mesmo Tribunal Regional Federal, afastando-se a invocação de paradigma da mesma Turma Recursal pela ausência de taxatividade legal e superação do posicionamento da Turma (Xavier; Savaris, 2009). Noutro panorama, pesa sobre os incidentes sujeitos à apreciação da Turma Nacional de Uniformização a divergência de julgados de Turmas de diferentes Tribunais Regionais Federais, que versem sobre a aplicação de lei federal ou contra a jurisprudência dominante do Superior Tribunal de Justiça. Ressalte-se que um único precedente emanado pelo Superior Tribunal de Justiça é suficiente para conhecimento do pedido de uniformização, desde que reconhecida a condição de predominância pelo relator, nos termos da Questão de Ordem 5, da TNU.

Faz-se necessário, contudo, averiguar a margem de impacto e a satisfação de toda a arquitetura recursal dos Juizados Especiais Federais. Em tese, duas intenções são claras, além do intuito inibitório de reexame das sentenças: resolução dos conflitos em primeiro grau de jurisdição e excepcionalidade na provocação das Turmas de Uniformização, todavia o diagnóstico quantitativo mostra-se diverso.

Partindo do exercício 2012, colhem-se os seguintes resultados: os Juizados Especiais Federais mantinham um passivo processual de 1.420.757 processos, foram peticionados 1.178 .802 novos processos, os julgados contabilizam 1.036.337; por sua vez, as Turmas Recursais mantinham um passivo processual de 862.343, restaram protocolados 459.044 novos recursos, e 447.681 foram julgados; Turma de Uniformização possuía em estoque 1.568 pedidos de uniformização, outros 2.588 foram ins- 
taurados, ao passo que 1.989 foram baixados. Logo, as taxas de congestionamento que se revelam dos processos perante os Juizados Especiais Federais, Turmas Recursais e Turma de Uniformização são, respectivamente: $43,5 \%$; $70,2 \%$ e $52,1 \%{ }^{19}$

Este primeiro dado é revelador: mesmo com todos os expedientes manejados, o sistema recursal dos Juizados Especiais Federais é o grande gargalo na efetiva prestação jurisdicional, provando a impotência na resolução dos conflitos em primeiro grau de jurisdição e a falácia existente entre os propósitos e as ações. Afinal, o referente de 47,57\% das decisões de primeiro grau que desafiaram recurso revela a baixa efetividade das sentenças e a propensão aos meios de impugnação dos julgados. Praticamente uma em cada duas ações ascendem à Turma Recursal. Apenas para expor um paralelo comparativo, nos processos de competência ordinária da Justiça Federal, este referente entre decisões proferidas em primeiro grau, presente o reexame necessário, bom lembrar, e a interposição de recursos orbita em 46,85\%. Ou seja, praticamente não há diferença no intuito recursal entre os dois paradigmas. Ademais, considerando tais dados e a redução de juízes nas respectivas Turmas Recursais, o tempo de espera para apreciação das razões recursais tende a se distender. Repita-se: no âmbito dos Juizados Especiais Federais os autos findos por meio de conciliação bloqueiam pretensões recursais, portanto a preterição do reexame necessário não fora efetivada.

Quanto o índice de provocação da Turma de Uniformização para pacificação jurisprudencial, que deveria ser excepcional, vislumbra-se o seguinte: das 447.681 decisões proferidas pelas Turmas Recursais, apenas

\footnotetext{
${ }^{19}$ Apenas para fins de comparação sistêmica interna, perante os Juizados Especiais estaduais e do Distrito Federal a taxa de congestionamento orbita em $52 \%$, por sua vez, as respectivas Turmas Recursais indicam 44,4\%. Tal informação replica a motivação recursal proveniente dos entes públicos federais em sede de Juizados Especiais Federais. Isto justifica a ampla procura recursal neste microssistema. Fonte: Conselho Nacional de Justiça. Relatório Justiça em Números. 2013.
} 
2.588 pedidos de uniformização foram interpostos, o que representa $11,58 \%$, podendo ser situado na margem de excepcionalidade. O otimismo, todavia, precisa ser deixado em suspensão em virtude da possibilidade de trancamento dos incidentes similares pelo caso paradigmático, que embarga múltiplas demandas nas instâncias intermediárias.

Alguns acordes dissonantes, no entanto, exigem análise. No ano judiciário de 2013, a Turma Nacional de Uniformização julgou 2.180 incidentes em 10 sessões ordinárias de julgamento, entretanto a informação mais alarmante e comprobatória dos argumentos descritos nesta tese registra a aprovação de 9 súmulas e 5 questões de ordem, isto é, para cada reunião da Turma editou-se mais de um verbete uniformizador de julgados. Inegavelmente há uma banalização mecânica de enunciados vinculantes. Não é somente este índice que causa espanto, porém. Dos 13.658 incidentes recebidos, o presidente da Turma produziu 11.575 decisões monocráticas; e o total geral de decisões publicadas foi de 11.705, ou seja, apenas 130 decisões foram debatidas pelo colegiado. No mínimo, uma disfunção crônica de um órgão colegiado, totalmente avesso ao modelo constitucional garantista de processo. Fiel, apenas, ao intuito uniformizador de julgados por critérios hierárquicos. ${ }^{20}$

\footnotetext{
20 “Confira as estatísticas da TNU de 2013: sessões ordinárias de julgamento 10; processos recebidos 13.658; processos autuados/registrados 13.530; processos distribuídos 1.757; processos redistribuídos 432; processos julgados 2.180; súmulas aprovadas 9; questões de ordem 5 ; decisões do presidente 11.575 ; despachos do presidente 36 ; decisões juízes relatores 37; despachos juízes relatores 36; acórdãos publicados 2.135; decisões publicadas 11.705; processos remetidos à turma recursal 5.658; processos remetidos à turma regional 37; processos remetidos ao STF 25; processos remetidos ao STJ 113; processos com baixa definitiva à origem 7.840; processos em tramitação 7.590" (Colegiado da TNU julgou 2.180 processos em 2013. Disponível em: <www.cjf.jus.br $\geq$. Acesso em: 6 fev. 2014.
} 


\section{O DEVER CONSTITUCIONAL DE MOTIVAR AS DECISÕES}

As linhas que se seguem conectam matérias de extrema relevância para a junção dos argumentos consignados. Ademais, são elementos essenciais na fixação de um modelo constitucional garantista de processo perante o sistema dos Juizados Especiais, o qual norteia, inclusive, os Juizados Especiais Federais.

Além dos vícios e virtudes já consignados, a flexibilização do dever constitucional de motivar as decisões judiciais proferidas representa a idiossincrasia-mor deste sistema, razão pela qual optou-se por abordá-la em tópico especial. Ainda que o cerne da questão passe por uma abordagem hermenêutica-constitucional, há que se ponderar que a permissividade em torno da fundamentação das decisões proferidas em sede de Juizados Especiais torna-se amplamente nefasta para a impugnação de julgados, vide os requisitos altamente formais para recebimento e conhecimento, bem como a ampla discricionariedade concedida ao juiz para a condução dos atos processuais sujeitos a sua jurisdição. Este contexto largo de liberalidades não se adéqua aos preceitos do Estado (liberal) de Direito, menos ainda ao Estado Constitucional Democrático. Em certa medida, não se materializa um juízo procedimentalista ou substancialista, mas o ressurgimento ativo das matrizes da Escola do Direito Livre.

Importante reafirmar a determinação constitucional contida no artigo 93, IX, da CRFB/1988, da obrigação inderrogável de toda decisão jurídica ou administrativa ser juridicamente fundamentada, sob pena de nulidade. Repita-se: a própria Constituição Federal impõe a nulidade como produto de processos “imperfeitos” em sua fundamentação. Tal preceito não se resume em sua própria existência, implica a materialização do princípio republicano (Barcelos, 2005), da dignidade da pessoa humana, da ampla defesa, do devido processo legal, dos meios de recursos e demais direitos e garantias fundamentais. 
A dispensa promovida pela Lei 9.099/1995, em seu artigo 38, do relatório em decisões de primeiro grau mostra-se como materialmente afrontosa com a Constituição Federal. Não se resume em lesão direta e imediata, mas em sonegação autorizada da exposição dos fatos relacionados aos atos processuais. Em um lócus no qual o juiz pode praticar os atos probatórios que julgar conveniente, indeferindo os demais (Marinoni, 2007); que pode alterar livremente os horários de expediente forense; em que as decisões interlocutórias em regra são irrecorríveis, possibilitar a dispensa de inscrição de tais atos na sentença apresentam-se como medidas inconstitucionais, pois impossibilitam a confrontação do tema nos recursos cabíveis. Reproduz o paradigma processual de Franz Kafka.

Não se pode tolerar e permitir a supressão direta e indireta de direitos constitucionalmente assegurados em favor de simplicidade, informalidade, celeridade e economia processual (Xavier; Savaris, 2009). Trata-se de inegável equívoco formal e material. E mais: trata-se de equívoco discursivo na manipulação dos princípios, haja vista sua preterição em sede de impugnação de julgados. Como isso é possível hermeneuticamente?

Não por acaso o sistema dos Juizados Especiais tenha habilidade para fornecer os melhores exemplos da resistência e da continuidade da compreensão da decisão judicial nos patamares do livre convencimento ou da vinculação à consciência do julgador (Wambier, 1996). Primeiro o julgador estabelece a decisão intuitivamente (aquilo que fora denominada de decisão freerider), ${ }^{21}$ nas cercanias do seu alvedrio, depois a bricolagem dos argumentos minimamente necessários para a fundamentação. Conforme lição de Lenio Streck, retoma-se, sempre, a constatação inicial: o problema

21 "Este es el caso del juzgador que oferece razones jurídicas para justificar su decisión, pero lo hace sólo para racionalizar - ex post - una decisión tomada intuitivamente, o sobre la base de motivos que no serían admisibles” (Redondo, 2009, p. 99). 
da democracia, da oxigenação constitucional e da necessária limitação dos poderes. Discricionariedade, arbitrariedade, inquisitoriedade, instrumentalidade, positivismo jurídico e jurisprudência de valores se conectam. ${ }^{22}$

Tal linha de confluência é potencializada quando da fundação de “estados pamprincipiológicos”, na expressão de Lenio Streck (2011), ou seja, a pseudocrença de que o Estado Democrático possa ser a pedra filosofal de legitimidade principiológica, podendo ser criados e permutados tantos princípios quantos necessários para fundamentação ad hoc das decisões. Vide princípio da instrumentalidade processual, princípio da cooperação processual e princípio da confiança no juiz da causa, segundo o qual o Tribunal deve pautar-se pela decisão do juiz da causa que teve melhores condições de contato com a situação fática, impondo ao Tribunal a "homologação do julgado em sua plenitude".

Este último princípio, em especial, aproxima-se substancialmente do disposto no artigo 46 da Lei 9.099/1995, o qual admite que nos julgamentos em segunda instância possam constar apenas da ata, com a indicação suficiente da demanda, fundamentação sucinta e parte dispositiva, podendo a sentença ser confirmada pelos seus próprios fundamentos, convertendo-se o acórdão em súmula de julgamento.

Está aí a chave do problema: as Turmas Recursais podem ser analisadas a partir do prisma de órgão meramente homologador de decisões que, originariamente, estariam sujeitas à reapreciação e eventual revisão,

\footnotetext{
22 "Embora Portanova reconheça que o 'sentenciar alternativo não é autorização para motivações arbitrárias' e que o 'juiz deve manter-se dentro de um sistema jurídico, mas com liberdade para assumir posição diante da lei, na busca de traduzir o sentimento de justiça da comunidade', mais adiante concorda com o próprio Fidélis dos Santos, citando-o, na linha de que 'não há nada que se sobreponha ao juiz, nem a própria lei'. Em outra obra não menos relevante, Portanova assevera que 'é difícil acreditar em algo que possa restringir a liberdade do juiz de decidir como quiser. É preciso reconhecer realisticamente: nem a lei, nem os princípios podem prévia e plenamente, controlar o julgador" (Streck, 2010, p. 35).
} 
com a reunião de argumentos jurídicos próprios. Não se observa sob este viés a necessidade de nova fundamentação quando da ocorrência de nova decisão, logo sujeito ao artigo 93, IX, da CRFB/1988.

Ao ser devidamente provocado, contudo, o Supremo Tribunal Federal, constitucionalmente guardião da Constituição Federal, absurdamente fixou em reiteradas decisões que "Não ofende o art. 93, IX, da Constituição do Brasil a decisão tomada por turma recursal que confirma a sentença por seus próprios fundamentos nos termos do art. 46 da Lei 9.099/95” (Brasil, 2014c).

Por sua vez, caudatária das orientações do Supremo Tribunal Federal, a Turma Nacional de Uniformização tem sedimentada a validade destes arremedos de fundamentação, exceto nos casos de decisão de Turma Recursal estranha ao processo em apreciação, eis excerto de manifestação: "Quando o acórdão decidir tema alheio à controvérsia, a Turma Nacional de Uniformização de Jurisprudência dos Juizados Especiais Federais deve anular o julgado” (Brasil, 2014d).

\section{CONSIDERAÇÕES FINAIS}

Adjetivados com a alcunha da mais inovadora mudança na Justiça nas últimas décadas, os Juizados Especiais foram concebidos para possibilitar de forma efetiva o acesso à Justiça, não somente ao poder Judiciário, por meio de jurisdição simples, barata e célere, condizente ao tratamento de causas de menor envergadura material ou pecuniária. Há de se destacar que o modo pelo qual se opera o sistema dos Juizados Especiais, em termos gerais, mostra uma (in)compatibilidade em relação aos preceitos constitucionais-processuais, que ganha relevo quando analisado o cenário do sistema de impugnação de julgados.

Ainda que com amplitude se defenda a existência de um sistema processual específico em torno dos Juizados Especiais, materializado inicialmente pela Lei n. 9.099/1995, a partir de determinações constitucionais 
(artigo 98, I, CRFB/1988), em termos práticos há uma opção viciosa e irrefletida pelo Código de Processo Civil sobre as bases comprometidas da Teoria Geral do Processo, mantenedora de razões estatais. Enfim, cumpre defender por fidelidade à Constituição Federal e ao modelo constitucional garantista de processo dela derivado a exigência do dever de fundamentar as decisões, inclusive intermediárias, como instrumento de monitoramento dos atos judiciais. Resitua-se, destarte, a compreensão garantista da Constituição contra arbitrariedades e discricionariedades. Para tanto, urge não se perder de vista a ideia de contraditório como força centrípeta.

Um microssistema preocupado na resolução dos conflitos majoritariamente em primeiro grau de jurisdição apresenta-se confuso ao admitir decisões judiciais desprovidas de relatório. A maior clareza e elucidação dos motivos conducentes à sentença para a população hipossuficiente promove máxima conformação com o produto da lide (tal como no caso Brown vs Board). Logo, reduz o percentual de sentenças recorridas. Os indicadores de produção devem perpassar por respostas jurisdicionais efetivas e corretas. Desconfianças alimentam recursos. A validade das decisões judiciais não se presume, nem pode ser presumida pelo aspecto formal ou pela investidura do órgão julgador; encontra sua acreditação na incorporação de argumentos jurídicos coerentes de qualidade (Ibañez, 2009, p. 103).

Em uma sociedade nitidamente excludente, como é a brasileira, defender piamente a onipotência dos procedimentos equivale, metaforicamente, à construção de uma residência que se principia pela colocação das telhas, ou ao bolo que se inicia pelo posicionamento da cereja. Em sede de processo jurisdicional certos valores e obrigações inscritos na Constituição precisam de satisfação. Aos procedimentos deve ser adicionada uma teoria de direitos e valores substantivos para que se efetive uma participação democrática nas tomadas de decisão. 


\section{REFERÊNCIAS}

BARCELOS, Ana Paula. Ponderação, racionalidade e atividade jurisdicional. Rio de Janeiro: Renovar, 2005.

BOCHENEK, Antônio César. A interação entre tribunais e democracia por meio do acesso aos direitos e à justiça. Análise de experiências dos juizados especiais federais cíveis brasileiros. 2011. Tese (Doutorado) - Universidade de Coimbra, Programa de Doutorado Direito, Justiça e Cidadania no Século XXI, Coimbra, 2011.

BRASIL. Conselho da Justiça Federal. Resolução n. 61/2009. Disponível em: <www.cjf.jus.br $\geq$. Acesso em: 11 jan. 2014a.

BRASIL, Tribunal Regional Federal da $2^{\text {a }}$ Região. Agravo de Instrumento n. 200702010116761, Rel. Des. Fed. Raldênio Bonifácio Costa. DJe 18/09/2008. Disponível em: <www.trf2.jus.br $\geq$. Acesso em: 10 nov. 2013.

BRASIL. Primeira Turma Recursal do Distrito Federal. Mandado de Segurança $n$. 200534007545820. Rel. Juiz Federal Alexandre Machado Vasconcelos. Julgado em 9/11/2007. Disponível em: <www.trf1r.jus.br $\geq$. Acesso em: 5 jan. 2014b.

BRASIL. Supremo Tribunal Federal. Agravo de Instrumento 749963. $2^{\text {a }}$ Turma. Rel. Min. Eros Roberto Grau, j. 08/09/2009. Disponível em: $<$ www.stf.jus.br>. Acesso em: 15 jan. 2014c. Vide ainda: AI 701043/2009, AI 624713ED/2007, HC 98.814/2009 e HC 86.533/2005.

BRASIL. Turma Nacional de Uniformização. Pedido de Uniformização 2004.81.10.00.5768-9, rel. Juiz Federal José Antonio Savaris, j. 16.11.2009. Disponível em: <www.cjf.jus.br>. Acesso em: 5 jan. 2014d.

BRASIL. Turma Recursal de São Paulo. Mandado de Segurança $n$. 201063010076231. Rel. Juiz Federal Claudio Roberto Canata. Julgado em 4/2/2010. Disponível em: <www.trf3r.jus.br>. Acesso em: 5 jan. 2014e. 
BRASIL. Turma Regional de Uniformização - $4^{\text {a }}$ Região. Autos 2005.7.60.002724-9-RS. Rel. Juiz Federal Andrei Pitten Velloso, publicado em 8/1/2010. Disponível em: <www.trf4.jus.br>. Acesso em: 15 nov. 2013. CAVALCANTE, Mantovanni Colares. Recursos nos juizados especiais. 2. ed. São Paulo: Dialética, 2007.

COLEGIADO da TNU julgou 2.180 processos em 2013. Disponível em: <www.cjf.jus.br>. Acesso em: 6 fev. 2014.

CONSELHO NACIONAL DE JUSTIÇA. Relatório Justiça em Números. 2013. p. 185.

CONSELHO NACIONAL DE JUSTIÇA. Relatórios Justiça em Números. 2007, 2008, 2009, 2010, 2011 e 2012.

GRINOVER, Ada Pellegrini. O tratamento dos processos repetitivos. In: JAYME, Fernando Gonzaga; FARIA, Juliana Cordeiro de; LAUAR, Maria Terra. Processo civil: novas tendências - estudos em homenagem ao professor Humberto Theodoro Junior. Belo Horizonte: Del Rey, 2008. p. 5.

IBAÑEZ, Perfecto Andrés. Justificación de las decisiones judiciales: una aproximación teórico-práctica. In: REDONDO, María Cristina; SAUCA, José María; IBANEEZ, Perfecto Andrés. Estado de derecho y decisionesjudiciales. Madrid: FundaciónColoquio Jurídico Europeo, 2009.

MARINONI, Luiz Guilherme Bittencourt; ARENHART, Sérgio Cruz. Curso de Processo Civil. 6. ed. São Paulo: RT, 2007. V. 2.

REDONDO, María Cristina. Sobre lajustificación de la sentencia judicial. In: REDONDO, María Cristina; SAUCA, José María; IBAÑEZ, Perfecto Andrés. Estado de derecho y decisionesjudiciales. Madrid: Fundación Coloquio Jurídico Europeo, 2009.

ROCHA, Felippe Borring. Juizados especiais cíveis: aspectos polêmicos da Lei 9.099/1995, de 29/9/1995. 5. ed. Rio de Janeiro: Lumen Juris, 2009. 
SANTOS, Marisa Ferreira dos; CHIMENTI, Ricardo Cunha. Juizados especiais cíveis e criminais: federais e estaduais. São Paulo: Saraiva, 2010.

SILVA, Luís Praxedes Vieira da. Juizados especiais federais cíveis. Campinas: Millennium, 2002.

STRECK, Lenio Luiz. O pamprincipiologismo e a "refundação positivista". In: COUTINHO, Jacinto Nelson de Miranda; FRAGALE FILHO, Roberto; LOBÃO, Ronaldo. Constituição \& ativismo judicial. Limites e possibilidades da norma constitucional e da decisão judicial. Rio de Janeiro: Lumen Juris, 2011.

STRECK, Lenio Luiz. O que é isto - decido conforme minha consciência? 2. ed. Porto Alegre: Livraria do Advogado, 2010.

VIEIRA, Luciano Pereira. Sistemática recursal dos juizados especiais federais cíveis. Doutrina e jurisprudência. Rio de Janeiro: Elsevier, 2011.

WAMBIER, Luiz Rodrigues. Apontamentos sobre os juizados especiais cíveis. Revista de Processo, São Paulo, v. 21, n. 82, p. 38-45, abr./jun. 1996. XAVIER, Flavia da Silva; SAVARIS, José Antonio. Manual dos recursos nos juizados especiais federais. Curitiba: Juruá, 2009.

Recebido em: 13/5/2014

Aceito em: $11 / 8 / 2014$ 